\title{
JUDICIAL MEDIATION: HOW IT WORKS THROUGH PRE-TRIAL CONFERENCE
}

\author{
FARRy M. FISHER*
}

$A^{\mathrm{r}}$ THE r94I session of the Illinois General Assembly, Section $58 \frac{1}{2}$ was added to the Civil Practice Act. It reads as follows: "Subject to such rules as the Supreme Court may promulgate the court in any action may in its discretion direct the attorneys for the parties to appear before it for a pre-trial conference to consider any matter as may aid in the disposition of the action."

This simple permissive statute is not so feeble as it appears to be at first glance. True, it is not mandatory, and only emphasizes a discretion inherent in the courts, but it does achieve the following objectives: (I) by giving legislative sanction to pre-trial conferences the practice became clothed with a garb of respectability; (2) responsibility for non-action is placed upon the courts; and (3) the courts which desire to promote the practice are enabled to do it effectively.

No such legislative action was necessary to authorize holding pre-trial conferences. Each court could by rule provide for them, and each judge could with or without rules hold a pre-trial conference in any case. In fact, some judges have for many years followed the practice of calling the contending lawyers into chambers for an informal discussion of the case before proceeding with the formal trial. But without legislation the practice would not have reached the position of importance it now holds, primarily for these reasons: (I) the bar is slow to accept change, and the courts were powerless to compel attendance of representatives authorized to act for the mere purpose of conferring; (2) the courts were without power to bind the parties to the results of any conference; and above all (3) many judges scoffed at the procedure, looked upon it as lacking legal sanction, and regarded it as something beneath the dignity of the court. Even long after the practice had gained acceptance in other jurisdictions and received the blessings of the Federal Rules of Civil Procedure, ${ }^{2}$ many judges in Illinois took (and some still take) the position that participation

* Assignment and pre-trial conference judge of the Circuit Court of Cook County, Illinois.

× Ill. Rev. Stat. (194I), c. Iro, § I82(a).

2 Rule I6, Federal Rules of Civil Procedure, 28 U.S.C.A. $\S 723 \mathrm{c}$ (I94I). 
by a judge in an informal conference before trial is not in keeping with the dignity of a court of law.

Following the enactment of Section $58 \frac{1}{2}$ of the Civil Practice Act, the Illinois Supreme Court adopted Rule 23(a), which enlarges somewhat on the legislative provisions but is not much more specific. It does, however, require that the trial court "shall by rule establish a pre-trial calendar, .... make and enforce all rules and orders necessary to compel compliance with this [Supreme Court] rule," and, further, that the trial court shall "make an order which recites the agreements made by the parties as to any matters considered and which limits the issues of the trial to those not disposed of by admissions or agreements of counsel."

Pursuant to this authority the Circuit Court of Cook County (and the Superior Court, in somewhat modified form) adopted a rather comprehensive pre-trial-conference rule. ${ }^{3}$ It provides that all jury and non-jury law cases when noticed for trial shall be assigned by the executive committee to a designated pre-trial-conference judge. It requires that the judge shall direct the attorneys in each case to appear before him at a fixed time for the holding of a conference, at which time counsel familiar with the case and authorized to act shall appear; and in the event of failure so to appear or to participate in the conference, the court shall have the same powers with respect to dismissal for want of prosecution or the entry of default judgment as it could exercise upon the call of the case for trial. Obviously, without power to compel attendance and participation in the conference, the practice could be nullified at the will of the interested lawyers.

Although the pre-trial-conference practice as an integral part of procedure in Illinois is less than two years old, its success in the Circuit Court of Cook County has been highly gratifying. The number of cases disposed of under the guidance of the pre-trial judge without trial has exceeded the fondest hopes of the advocates of the system. For the first time in more than half a century, the congestion of the Circuit Court's calendars has been relieved, so that parties desiring it can have their contested cases tried within four months of their commencement. In April of this year a considerable number of jury and non-jury cases commenced in I943 were reached for trial, and very few cases appeared on the calendars which had been commenced prior to 1942 .

Owing to the nature of the administrative organization of the Circuit Court, its pre-trial-conference practice differs somewhat from the practice followed by the Superior Court of Cook County and by courts in other jurisdictions. Under the Circuit Court rules no common law case

3 Rule $25 \frac{1}{2}$, Circuit Court of Cook County. 
(except an extraordinary remedy case) is assigned to any particular judge before it is ready for immediate trial. Until such a case reaches the assignment judge it is under the control of a motion judge, who settles the pleadings and passes on all motions. After the case is at issue, either party may serve notice of his readiness for trial. ${ }^{4}$ When the notice is filed with the clerk the case is automatically placed on a trial calendar in the order in which the notice is filed. That calendar is under the control of an assignment judge who has the authority to try any case or to assign it to any other law judge for trial.

Prior to April of this year it was the practice of the assignment judge to maintain and publish a reserve list of approximately 300 cases from which the daily trial call was prepared. But by the middle of April both the trial calendar and the reserve list were exhausted, and since then cases noted for trial appear on the daily trial call on the first Monday following the filing of the notice.

No pre-trial calendar is in fact prepared. All cases are called for and are subject to immediate trial when they first appear on the daily trial call. On that day, if the parties are ready, the pre-trial conference is held; otherwise, the case is set for conference on a fixed future day. When set for trial after conference it is not subject to continuance except on legal grounds.

When the court decided to experiment seriously with pre-trial conferences, two questions arose: ( $\mathrm{r}$ ) at what stage of the proceeding and how long before trial should the conference be called, and (2) should the motion judge, the assignment judge, or the trial judge preside over the conference?

It became clear that time would be wasted if the conferences were held before the pleadings and preliminary motions were settled, since many cases are finally disposed of on the pleadings or on motions for summary judgment. This, of course, eliminated the motion judge. It was likewise decided that the trial judge should not preside over the pre-trial conference. Lawyers would feel, rightfully so, that no judge could successfully detach himself from the information absorbed during the conference or escape forming views on the merits of the case which might unconsciously color his rulings at the trial. Finally, experience had shown that lawyers will not enter a pre-trial conference earnestly until their case is subject to immediate trial. Consequently, it was decided that the assignment judge should preside over the conferences. This decision has been fully justified by the results.

4 Rule 22, Circuit Court of Cook County. 
The daily trial calendar of the assignment judge who feeds, so to speak, nine trial judges, is made up of two parts. Calendar A, which is called fifteen minutes before the trial courts convene, consists of cases which have passed through all the pre-trial stages, including conferences and motions for continuance, and are subject to immediate assignment for formal trial. Calendar B is called thirty minutes later and consists of cases which may be subjected to trial, to pre-trial conference, or which may be continued either upon agreement of the parties or for good cause shown upon motion of either party. Cases which appear on the daily trial call for the first time are rarely ready even for pre-trial conference. A date convenient to the parties is then set, at which time the conference is to be held. However, this is not to be treated as a pre-trial-conference calendar. Because some doubt is entertained on the validity of the rule which empowers the court to dismiss a case or to strike the defendant's pleading for failure to attend a pre-trial conference, all cases are called for trial even upon their first appearance on the daily calendar. The parties must respond as for trial, but before actual assignment to a trial judge is made the conference is held. This not only obviates consideration of the validity of the rule in question but, as will be seen later, it is conducive to better results from the conference because the parties must decide whether they should settle the case or go immediately to trial.

The conferences are informal. The parties sit around the judge's desk in chambers; they may even smoke, if they desire. The plaintiff's counsel makes a brief statement of the nature of his case and the theory or theories upon which he predicates his claim. The defendant's counsel then states the nature of his defense. A discussion follows in which the judge participates quite freely. He often requires the production of exhibits, including photographs, X-rays, and, where those are available, doctors' and hospital records and bills. Police reports of accidents, writings, deeds, discovery depositions, and witnesses' statements are examined by the judge without regard to their competency or incompetency as evidence. Often, upon request of a party, the judge indicates his views upon the admissibility in evidence of a particular exhibit. If no final disposition of the case is made, the court certifies all matters agreed upon in order to obviate as much as possible the necessity of making preliminary or merely formal proof. But such certifications are exceedingly rare. The great majority of lawyers are cooperative and rely upon the promises of their adversaries with reference to the elimination of proof. But by far the most gratifying and valuable gains from these conferences are derived from the amazing volume of final dispositions brought about by amicable settlements. 
Through all the oral and written discussions on the value of pre-trial conferences there seems to run an apologetic note with respect to settlements. The advocates of pre-trial conferences are always lukewarm in their emphasis upon settlements. The object of the conference, they say, is to settle the pleadings, to simplify the issues, to reduce the quantum of proof, to limit the number of expert witnesses, and, in general, to aid the orderly and speedy disposition of cases. It is a sort of time-saving mechanism. In fact, it will be observed that in drafting the Rules, Federal and State, the authors carefully avoided the use of the word "settlement" or its equivalent.

The experience with pre-trial-conference procedure as it operates in the Circuit Court of Cook County should convince any observer that the great value of this practice lies in the number of final dispositions of cases it procures. It has already been pointed out that during this first and largely experimental year of legally sanctioned pre-trial conferences the Circuit Court has so cleared its law calendars that a trial may be had of any case within a month after the parties have informed the court that they are ready for trial. This was done without increasing the number of trial judges. In fact, in the last two months some of the law judges have, for respective periods of several weeks, been relieved of their regular assignments and appointed to other branches of the court.

It was not so long ago that a law case started in the Circuit Court would not reach trial before the lapse of two and more often three years. The victims of this condition suffered not only from justice delayed but also frequently from justice denied. Errors in pleadings or in the naming of parties when discovered at the trial were usually fatal because the statute of limitations was an effective bar to any cure by amendment. Today, the only cases not reaching trial before the running of the statute are those in which the parties unduly delayed filing or failed to prosecute diligently.

This result, which in the Circuit Court eliminated the injustices flowing from the law's interminable delays, was brought about primarily by settlements encouraged during pre-trial conferences. The experience during the expiring court year has been that for every case assigned for formal trial at least four other cases were settled in the chambers of the assignment judge. Often as many as twenty and seldom less than five cases are settled in a single day.

In the beginning, a large portion of the bar frowned upon the practice. They attended the conferences but participated in the discussions only reluctantly. When ordered to disclose evidence or to submit a plaintiff to physical examination in connection with claimed existing injuries, re- 
spectful indifference changed to vehement protest. But, as compliance was universally required and the results thereof evaluated, resistance lessened until now it has all but disappeared. The force of the indisputable progress was inescapable. Cases were being settled. Congestion of calendars was dissolving, and.lawsuits were reaching trial within a few months of their starting date. That was something which transcended the fondest hopes of plaintiffs' counsel. They began to flock to the Circuit Court with their lawsuits. Instead of 40 per cent- the normal quota as between the Circuit and Superior Courts ${ }^{5}$ - the figures in law cases in the Circuit Court continued rising, until now they reach approximately 70 per cent. Moreover, even defendants' lawyers learned to appreciate the advantage of discussions with their adversaries and the benefits of disclosures made during the conferences. Particularly do they appreciate the value of medical examinations of plaintiffs, a right which is now attainable without objection by plaintiffs. Pressed in the early stages of the experiment, the contention that the court has no power to compel submission to physical examination is hardly ever made now. The very nature of the discussion before the pre-trial-conference judge leaves the plaintiff's lawyer in an unenviable position if he withholds consent to such an examination. While a plaintiff on the witness stand in a formal trial may not be asked whether he will submit to a medical examination because his refusal might prejudice the jury, ${ }^{6}$ no such prejudice can be claimed when the request is made at the pre-trial conference. The plaintiff is asking for a certain amount of money on the basis of claimed injuries. His counsel's position becomes at once untenable if he declines to submit to a proposed examination, under safeguards fixed by the court, to determine whether those injuries really exist. He is confronted with the alternatives of granting the request or ending negotiations. He submits. Incidentally, in the opinion of the writer, the court has inherent power to compel such submission, but that question is beyond the scope of the present discussion. So effective are these examinations that it is only the rare case that does not result in a settlement after the examination. The following case illustrates its effectiveness.

A, a passenger in a taxicab, was thrown from his seat when the cab in which he was riding collided with another. He did not realize that he was hurt until he attempted to alight from the cab upon reaching his destina-

$s$ The Circuit and Superior Courts of Cook County are courts of co-equal jurisdiction. The Superior Court has twenty-eight judges, the Circuit Court, twenty; although the latter employs, on the average, four downstate judges.

6 Mattice v. Klawans, 3 I 2 IIl. 299, I43 N.E. 866 (r924); see also, Chicago, Rock Island \& Pacific Ry. Co. v. Benson, 352 Tl. I95, I85 N.E. 244 (I933); City of Chicago v. McNally, 227 III. I4, 8I N.E. 23 (IgO7); cf. People v. Scott, 326 Ill. 327, I 57 N.E. 247 (I927). 
tion. He found himself unable to stand on his feet. He was taken to a hospital where it was discovered that he had suffered a nerve injury, probably from a clot on the brain resulting from a ruptured blood vessel. $\mathrm{He}$ had been afflicted with high blood pressure for several years before the accident. For six months thereafter he was bedridden. His doctors failed to agree on diagnosis or prognosis. He was represented by a high-minded, honorable lawyer, who at the pre-trial conference demanded $\$ 35,000$ in settlement, on the basis of advice that his client would probably never walk again. The defendants admitted liability but refused to discuss settlement unless they were permitted to examine the plaintiff to ascertain the extent of his injuries. The plaintiff's lawyer readily admitted the reasonableness of the request, but his client refused to consent. The lawyer asked for the privilege of bringing his client into court and expressed the hope that the judge would prevail upon the plaintiff to give his consent. He was brought into the judge's chambers on a stretcher. It was apparent that the plaintiff honestly believed that his injuries and consequential incapacities were permanent. His wife was with him and pathetically avowed that she would be little concerned with the amount of compensation obtainable if only her husband could ever regain the use of his limbs. The court did prevail upon the plaintiff to submit to an examination by a disinterested physician, upon whom both sides would agree, and who should report directly to the court. The examination was had, and the case was diagnosed to the apparent satisfaction of both parties. The plaintiff was assured that with a few months' re-education he not only would be walking again but would be able to resume his normal course of living. The case was settled for $\$ 6,000$. This case is only one of a great number having similar results.

To such an extent has the bar recognized the value of dealing with negligence cases in a simple, businesslike manner before venturing upon a formal trial, that out of one short year's experimentation there is already evidence of a developing practice of pre pre-trial conferences between the lawyers themselves. Knowing that they will be compelled to confer in the presence of the judge, many lawyers now hold conferences in their offices in advance of the pre-trial conference. In an increasing number of cases the lawyers inform the judge that they have anticipated the conference and spared his time and labor by agreeing to a settlement.

The relative number of settlements would increase materially but for certain evil customs for which no remedy has as yet been evolved. Two derive from the defendant's side and one (of more recent origin) from the plaintiff's side.

The majority of defendants' lawyers appearing in negligence cases rep- 
resent transportation or insurance companies. One obstacle to settlements comes from the fact that these lawyers are paid on a per diem basis. Usually the rates are low for preparation and much higher for actual trial work. When a case is settled, the defendant's lawyer loses the greater portion of the fee which he would have earned had the case gone to trial. The busy lawyers are reconciled to this. They realize that since they are paid for each day's work and no more and have ample work to occupy them every day, it doesn't make any difference whether their fees are earned in one case or another. Moreover, they receive payment for their labors only after the final disposition of each case, and the more cases they settle the more money they earn, at least immediately. But a large number of lawyers who depend for their income almost exclusively on defense work and have not enough of that to consume all their available time, say that they cannot afford to contribute their fees as an inducement to a settlement. They argue that every settlement is a give-and-take proposition as between the parties, but as to the lawyer working on a per diem basis, it is all giving without compensatory taking. Consequently, cases which ought to and could be settled often go to trial, and after the lawyer has earned a fee for a day or two spent in court a settlement is effected. Sooner or later the bar will have to work out a solution for this problem. Some way must be found to fix standards of compensation for bringing about just settlements commensurate with the value of the services rendered rather than on the sole factor of time consumed.

The other obstacle derives from the peculiar relationship in which the lawyer representing insurance companies stands before the courts. So far as the court is concerned, the lawyer represents the defendant, not the insurance company. In fact, however, he does not represent the defendant at all: his client is the insurance company. He feels that his first duty is to guard that client's interest, and when its liability is limited by the policy there is no inducement for settlement where the amount asked by the plaintiff is the full limit of the policy. The fact that the principal whom he represents of record might be held for a sum in excess of the amount that his real client can be called upon to pay does not seem to concern him very much. The plaintiff and the real defendant may be anxious to settle for the amount of the policy but the defendant's lawyer is not interested unless he can strike a satisfactory bargain for his client-the insurance company. The following case illustrates the awkwardness of the situation and points to the necessity for a re-definition of the duties between a party to a lawsuit and his lawyer when the latter's allegiance is not to the client whom he legally represents and should protect, but to 
some other person who pays him for his services. In the case in question the plaintiff (a woman) was standing on the sidewalk at a street intersection. The defendant (also a woman) was driving her automobile in a southerly direction when suddenly it swerved and ran onto the sidewalk and against the plaintiff, injuring her seriously and permanently. A recovery of $\$ 25,000$ or more was clearly predictable. The driver of the car carried accident insurance to the amount of $\$ 5,000$, but when the plaintiff offered to take that amount in full settlement the defendant's counsel insisted that there must be some inducement to the insurance company to settle. He did not question the liability, neither did he deny that $\$ 5,000$ was grossly inadequate compensation for plaintiff's damages, "but," he said, "we have nothing to lose by going to trial. Our liability is limited to $\$ 5, \infty 00$." The court reminded the lawyer that he is an officer of the court and that his duty to the court and to the defendant whom he legally represents demanded that he save the time of trial and avoid the risk of a verdict and judgment against his principal far in excess of the amount which the plaintiff was willing to accept. But counsel remained adamant. Unless some concession were made to the insurance company, the case would have to be tried. The plaintiff, against the advice of the court, accepted $\$ 4,300$.

Insurance carriers other than accident companies pride themselves upon their promptness in discharging their obligations. Possibly a similar result would be obtained with accident insurance carriers if the courts would insist that counsel of record be bound by only one allegiance and that he accept no hire from any person other than the person whom he represents of record, where he is paid by another, that that fact should be made known to the jury. In return for the special protection accorded insurance companies by the rule which prohibits informing juries who the real party in interest is (and that rule applies only in favor of insurance companies), such companies ought to cooperate eagerly with the court in every effort to save its time and obviate the necessity of a protracted jury trial where, as in the case above recited, the facts demand amicable adjustment.

Still another obstacle to settlements has its source in a new practice which has developed quite universally in dealings between plaintiffs and their lawyers. Practically all negligence cases are prosecuted by the lawyers on a contingent fee basis. In the past the lawyer's share, fixed by contract, was the same whether recovery was made as a result of a settlement or by verdict and judgment. Latterly, the custom has grown up to provide that in case of settlement the lawyer's share should be 25 per cent of the amount recovered and in case of trial the share should be $33 \frac{1}{3}$ 
per cent or more. It is not uncommon practice for plaintiffs' lawyers to avoid settlement until after the trial of the case has commenced and the higher fee has been thereby earned under the contract.

These obstacles, very common during the experimental days of pre-trial conferences, are constantly lessening. The bar is realizing more and more that the pre-trial conference has become an integral part of our procedure and that the lawyer on each side of a case has a duty to the court to bring about a disposition of the case at the lowest cost to the community. The operation of a courtroom with a jury costs the taxpayers approximately $\$ 150$ a day. Moreover, a great number of plaintiffs' lawyers now appreciate the value of obtaining early trials and are therefore glad to make their contributions to the practice which insures it. Defendants, especially those who have a great volume of litigation, are gradually beginning to realize that it is to their advantage to pay their lawyers liberally for bringing about a desirable settlement. The following discussion with a representative of an insurance company which is defending a large number of cases illustrates the consciousness that settlements are advantageous to the insurance carriers. The court, pointing out the unfairness of requiring a lawyer to contribute his entire prospective fee in order to bring about a settlement, suggested that under such circumstances the client might not always get the best advice from his lawyer on the matter of settlement. The reply was: "Judge, you're dead right. I find that my lawyers, before going to trial, assure me that they can beat the case and advise that I pay nothing, or but little, in settlement. After the case has been on trial for one or two days they suddenly become jittery and point out how disappointed they are by such and such testimony or by such and such action of the court, and usually I settle for twice the amount or more than I could have settled before the case went to trial."

By far the greatest number of cases on the law side of the court are negligence cases. With the exception of agreements to waive preliminary proof for the introduction of exhibits, on the number and qualification of expert witnesses and, occasionally, on the agency of the driver and that he was engaged in his principal's business, little else can be agreed upon at the pre-trial conference. It happens once in a great while, however, that a defendant admits liability in the hope that he will thereby exclude from the jury repetitious descriptions of a gruesome accident.

Desirable as these agreements may be, when considered solely as a time-saving device, in tort cases they are only of measurable significance. In such cases settlements count. In contract cases, on the other hand, while the ratio of settlements does not compare favorably with those 
made in tort cases, the time saved by admissions and agreements is formidable. As a rule, the conference results in reducing the controversy to one or two simple issues.

In stressing the value of settlements of negligence cases, it is not alone the economy of the trial and reviewing court's time that is important. Of course, the facts that the calendars are cleared, congestion eliminated, and the court made free to devote itself to cases which can be disposed of only by formal trial are of significant importance. But that represents only one of the great benefits. As has already been indicated, a major achievement is the possibility of going to trial before the statute of limitations has run and in time to correct errors without being deprived of a hearing on the merits. But there is another and extremely important social gain resulting from settlements of negligence cases. Settlements bypass what thus far has remained an indestructible barrier to progress in the law of negligence. The rules which fixed the relative duties of pedestrians and drivers of teams of horses on the King's unfrequented highway are now applied to pedestrians and operators of powerful and deadly machines monopolizing the streets of congested modern cities-machines capable of developing speeds which the ancient judges could not, in their wildest imaginations, have deemed possible. Children at play are literally driven off the public streets even where no other room is left to them; pedestrians are denied the use of those streets, save at intersections, and there only long enough to "steal" across the road while the green light is on. Yet, in every case of injury to a pedestrian-without regard to his probable momentary confusion resulting from the din of noises and bewildering traffic - the jury is told that the driver of a powerful machine is not required to use any greater care than the pedestrian and that if the latter is guilty of slight negligence he cannot recover even though the driver was admittedly reckless.

The law as it is administered by juries in this field has no greater relation to justice than had the verdict in an ancient trial by battle to the merits of the case. Certainly the public interest in just compensation for avoidable disabilities inflicted upon its citizens and in the possibility that they or their dependents will thereby become public charges gets no consideration in the prevailing system of "justice."

Where the court successfully mediates in such cases, however, a different over-all result can be obtained. Excessive recoveries-often the result of passion or prejudice of jurors-and unjust denials of recovery are reduced to a minimum. The aggregate sums which otherwise would be paid out by defendants in judgments and costs are spread over a much 
larger number of sufferers from accidents. When during the court's effort to mediate it becomes evident that in the event of a trial the case will go to the jury, both parties become conscious of the gamble involved; and they are at once confronted with the decision of whether, in view of the settlement which can be made, the wager of the client's money is justified.

In the mediation proceedings in the Circuit Court the principles underlying the workmen's compensation system are to some extent looked to. It is better that a larger number of sufferers from accident receive some compensation than that a few get mountainous verdicts and others recover nothing at all. This spirit not only pervades the pre-trial conference room but has found acceptance by all the trial judges who very frequently succeed in settling cases where the pre-trial judge has failed. Very often cases of questionable liability are settled on the plea that, morally, the person who inflicted the injury should bear at least part of the loss.

Most of the lawyers appearing at pre-trial conferences have caught the spirit and their cooperation is largely responsible for the unparalleled success of the experiment. Not infrequently the lawyers on both sides of a case agree on what would be a reasonable settlement, but one or the other fails to convince his client to accept. In such a situation the lawyer usually turns to the judge for help, and the judge seldom fails him. In the case of the doubting or unreasonable plaintiff, the following simple question addressed to him by the judge inevitably has a salutary effect: "Suppose you had the money which is now offered you lying in the bank; would you take it out and wager the whole of it on the possibility of getting twice or even three times the amount from the uncertain hands of a jury, risking, however, the possibility of getting much less or nothing at all?" The answer is always "No."

Just a few concluding thoughts on the contention still occasionally made that the dignity of the court suffers by the judge's participation in conferences aimed at bringing about settlements. Actually, nothing so lowers the dignity of the courts or so weakens public confidence in them as the indefensible delay and the injustices resulting from pure formalism. On the other hand, nothing would so enhance the prestige of the courts as the employment of a sane, businesslike method of composing private disputes-methods which the litigants could understand and in which they would be permitted to participate.

Private litigation belongs to the parties, and it is for them to settle their controversies, before or after suit, in whatever manner they choose. Except in cases coupled with some public interest or in which persons laboring under legal disability are involved, the court should encourage 
amicable settlements. The law favors it and as an inducement provides immunity against disclosure of matters occurring during negotiations for settlement. Even admissions of liability made during such negotiations are excluded from evidence. ${ }^{7}$ How then can the court's dignity suffer by inviting the litigants to negotiate in its presence, so long as it is made clear that the final decision lies with the parties? Compare the respect in which a court is held which refuses to encourage settlements, but whose calendars are so congested that it takes two or three years before a case reaches trial, with the respect accorded to the courts in which cases are disposed of with reasonable dispatch-even though the judges of such courts dispense with formality, remove their robes, and sit around the table with the parties with a view toward settling controversies. The volume of litigation brought to the Circuit Court points to the answer.

The self-proclaimed dignity of the courts is not accepted as compensation for injustices resulting from the law's delays, and for their pious formality the courts are frequently rewarded with contempt and disrespect. The impatience of the public with the stubborn resistance by many courts to improvement of their methods can be read in those legislative measures which are progressively whittling away the powers of the courts and to an ever increasing extent entrusting judicial functions to administrative agencies.

Unfortunately, not even the ablest judge is endowed with the mental capacity to insure absolute justice in every case. Certainly, formal trials, with or without juries, do not insure it. The courts are placed in the social pattern as sentinels to guard against violent settlements of controversies. Those who enter their portals come with the expectation of obtaining settlements of their disputes according to their concept of justice, but in reality all they receive through a formal trial is an imposed settlement according to the forms of law. When these forms are followed, the result, just or unjust, must be accepted by all concerned. To avoid the possibility of a legal judgment which fails to do justice, compromise through mediation is the most effective instrument available to the parties.

7Rockafellow v. Newcomb, 57 Ill. I86 (1870); Graff v. Fox, 204 IIl. App. 598 (IgI7); McMaster Car Supply Co. v. Phoenix Electrical Co., 209 Ill. App. 347 (19r8) (abstract). 